\title{
Economic Exploitation of Working Class under Dogras 1846-1952.
}

\author{
Dr Syed Damsaz Ali Andrabi ${ }^{1}$, Dr. Mohd. Yousuf Bhat ${ }^{2}$ \\ ${ }^{I}$ (Lecturer, Department of Higher Education, Jammu and Kashmir) \\ ${ }^{2}$ (Assistant Professor, Political Science, Department of Higher Education, Jammu and Kashmir)
}

\begin{abstract}
The socio-economic conditions of people were equally depressing. The rules and regulations of caste hampered social mobility, fostered social divisions and snapped the individual identity. Muslims were discriminated not only on economic front but also the rulers interfered with their religious liberties. Numbers of Muslim religious places were turned into store houses for food grains and ammunition centers. Proprietary rights of land were confiscated. Newer unknown and unjustified taxes were imposed on subjects. Each and every appointed officer used to oppress the people as much as he can. Skilled workers in normal days were not in a position to take two time square meals. Whatever was earned was snatched forcibly from them. The world reputed Shawl and Silk industries declined. Workers used to work from early morning to late evening still they earned nothing. While realizing the attitude of rulers number of movements came into existence to fight against the autocratic rule to save the people from sufferings.
\end{abstract}

Keywords: Social distinctions, Land Rights, Industry, Exploitation.

\section{INTRODUCTION}

Kashmir for centuries has remained the object of attention for scholars, poets and philosophers. The beauties of Kashmir have also been the causes of its outside intervention in course of her history. The Tartars, Hindu Princess, Mughals, Durranies of Kabul, Ranjit Singh, the Sikh and finally Gulab Singh the Dogra have successively subjugated this beautiful land. The culture of valley has drawn its strength and sustenance from various sources, influencing and getting influenced by these forces at work. Hindu officials used to oppress the Muslim majority of Kashmir in order to perpetuate their monopoly over the state services. They devised every possible means to close the doors of government offices to them. Worse, it was a common practice among the officials to insult their subjects, even the most respectable among them. Though each section of the Muslim community was simmering with discontentment owing to the oppression Kashmir was reeling under. The fact remains that the most discontented lot was the peasant class, the biggest segment of the population of Kashmir. The causes of their discontentment were many, but the most crucial were the confiscation of proprietary rights of land and the oppression they were subjected by the state and its supporting structure, jagirdars, chakdars, and maufidars.

Like any medieval society, the social formation of Kashmiri society during the period was feudal. As the major portion of the peasants produce was appropriated by the state and its collaborators. Immediately after the Dogras took over as the rulers of Kashmir in 1846.A.D, they declared the whole land of Kashmir as the state property, while this declaration was obviously aimed at legitimizing the maximization of land revenue and other demands. Its purpose was the revoking of land grants enjoyed by the Muslim- jagirdars, maded-i- mash holders and to create a new supporting structure. The new elements were mainly recruited from the Hindu community who were considered the only faithful subjects to rely upon. A big portion of land was appropriated by the Jagirdars, chakdars and maufidars. This can be gauged by the fact that more than 12 percent of the total revenue of the state was assigned for Jagirs and maufts. In Kashmir valley alone an area of 2,91,689 acres was under the various categories of land lords.

The Dogra rule was ushered in by many backward policies. But the most regressive step taken by it was the confiscation of proprietary rights in land which the Kashmiri peasantry was enjoying without any interruption since the earliest times. In the new circumstances the government became a farmer, working with coolies under a management closely approximating forced labour. The peasants lost not only the proprietary rights but also the occupancy rights. As it was only the Kashmiri peasant whose proprietary rights on land were confiscated. The new land policy did not apply to Jammu peasants. They continued to enjoy the proprietary rights on land, obviously because the Dogra rulers always considered Jammu as their home and Kashmir as the conquered territory. It was at the instance of the strong recommendations made by A. Wingate and his successor settlement officer, Walter Lawerence, that occupancy rights were conferred upon the peasantry in 1894-95. But the peasants of the Jagirs, chaks and maufis continued to remain as tenants at will. Thus while the majority of 
the peasant population working in the land held as khalsa enjoyed occupancy rights on the eve of the foundation of the Muslim Conference in, 1932.AD, a good number of peasants were no more than farm-labourers. However, the mere conferment of occupancy rights did not satisfy the peasantry, as the confiscation of proprietary rights in land was not only regarded as serious interference in the rights of the peasantry, but it was also considered tantamount to denigrating, uprooting and dislodging the peasant population. It took the hearts of the peasantry out of cultivation. The confiscation of proprietary rights in land was used as a weapon by the state to legitimize its policy of rack- renting. Small wonder then, which the restoration of the proprietary rights in land figured among the important demands made by the Kashmiri leadership through their memorandums right from the day of burgeoning signs of consciousness among the Muslims of Kashmir. In this context the memorandums were presented to the government by the Kashmiri Muslims in 1924 and 1931.

Zamindars of Kashmir were deprived of proprietary rights over their lands, whereas those of Jammu fully enjoy those rights. The people of Kashmir could not sell or mortgage their lands on their own will. They could not even cut the mulberry, the walnut and the chinar trees grown on their private lands or make use of them, nor they could remove dead and fallen timber of such trees, with the result Kashmiri Zamindar was no better than a mere tenant. There was no reason to make a distinction between Kashmir and other parts of the state (Jammu). No government has the right to sell the proprietary rights of the lands belonging to the people.

It is important to mention that the restoration of proprietary rights in land was one of the main issues on which the struggle of Muslim Conference centered. And it was owing to its struggle that the demand was exceeded to in 1933. However, even after 1933, a sizeable peasant population viz. those who were working in jagir, chak and maufis lands continued to remain either mere crop sharers or tenants- at - will. The confiscation of proprietary rights in case of marusi peasants of Kashmir and the creation of new class of tenants-at-will by the grant of chaks and jagirs, was a sufficient cause of generating deep resentment among the peasant masses. However, the oppressive policy of the government and its collaborators viz. landed aristocracy and the revenue functionaries, angered them beyond any scope for reconciliation. The high pitch of land revenue and other taxes, the faulty method of land revenue assessment and collection, the exaction of illegal taxes ( rasum), the beggar and the gross neglect of the basic problems of the peasantry by the state and the landlords were their main grievances.

In 1932.A.D, the magnitude of land revenue in case of the khalsa land of Kashmir valley was $1 / 3$ of the gross produce. Strangely enough, it was lighter in Jammu as only $1 / 4$ of the total produce was charged as land revenue there. The high pitch of land revenue demand borne by the Kashmiri peasant can be inferred from a complaint submitted by a Mirpur peasant though he was lightly taxed in comparison to his Kashmiri counterpart. According to him he had to pay Rupees 51 for 85 bighas situated within the boundaries of Jammu and Kashmir State, whereas for the same area of land located within the jurisdiction of Punjab, he had to pay only Rupees. 10 and 8 annas.

The method of revenue collection and mode of payment was also oppressive. The state realized its share both in cash as well as in kind. While $2 / 3$ of the assessed revenue was paid in cash, 1/3 of it was paid in kind. The rates fixed for paddy and other crops were very high. Naturally, the Kashmiri peasants who always suffered for want of currency had to depend upon money lenders commonly known as "waddars" in Kashmir, who while exploiting the helplessness of the peasantry, loaned them money on high interest and purchased their grains at very low rates. Thus while on one hand peasant was exploited by the state by charging exorbitant rates of the revenue, on the other hand, he was also fleeced by the "waddar". The payment of $1 / 3$ of the land revenue in kind, known as mujawaza, caused much havoc to the peasantry because by scanting away $1 / 3$ of the produce in kind the peasant was left with a small quantity of produce hardly sufficient to fulfill his basic food needs for few months. It can be properly understood when it is borne in mind that in Kashmir only one crop was raised in a year and that the per trakh (forty marlas of land) productivity of land was not more than 2 (160 kgs) to 4 (320kgs) kharwars.

It may also be noted that the orders of 1891 and 1920 regarding the abolition of beggar did not apply to the construction of canals, embankments etc . As a matter of fact, till 1947, it was obligatory upon the villagers to construct and repair the canals and embankments besides helping the rulers and high officials in the hunting pursuits and to peddle the boats of the royal river processions without any remuneration. And if anyone showed negligence, he was harshly punished and fined. The construction of Gilgit menace still haunted the mental peace of many villagers, particularly those living near the road and those who were in possession of horses, mules and asses as they were often forced to carry the loads known as rasad. The whole burden of beggar (forced labour) fell exclusively upon the common Muslim peasantry as the Hindus, Syeds, Thakurs, Rajputs and Sikhs were exempted from it. This was no less a source of resentment among the Muslims of KashmirThis is why the Glancy Commission,1931.A.D, recommended that when a requisition for labourers for Kar-i- Sarkar would arrive in a village, the agricultural community have to obey it all costs. The continuous struggle of people under the leadership of National Conference ultimately provided them some sort of relief as the abolition of Jagirdari system in valley. 
The fact that a large area of land was under the possession of the different categories of landlords can be inferred from the fact that immediately after the end of Dogra rule, 55 lakh kanals of land were transferred to the tillers by passing the famous "Abolition of big landed Estates Act" 1950. By virtue of this Act only that land was transferred from the landlords who exceeded 182 kanals and the orchard and maufti lands were exempted from it. Though this Act was only a beginning towards the abolition of landlordism in Kashmir, by virtue of it, 396 big Jagris were revoked and 2 lakh and 50 thousand tillers became the proprietors of land.

Next to the peasantry the biggest segment of the population comprised of the skilled and unskilled labourers coming mainly from the urban centres especially Srinagar and exclusively belonging to the Muslim community. Their woeful condition and unrest among them find repeated mention in the socio-religious and cultural history of Kashmir. It was because of several factors firstly, the demand of Kashmiri goods in European markets had heavily suffered because of the Franco- German war of 1870 and the economic depression of 1929. Secondly, the importation of machine made goods had caused severe blow to many indigenous industries, throwing a lot of people out of employment and the state showed no interest to preserve the traditional crafts of Kashmir. At the same time, because of the influx of currency and increase in the imports over exports, prices of basic necessities had sore very high.

The shawl industry was the leading industry of Kashmir till 1870. The industry alone employed about, 29115 Muslim shawl- weavers besides an innumerable number of spinners. However, in spite of being the backbone of Kashmir's economy, the shawl- weavers were the worst hit of oppression. They were exorbitantly taxed and like serfs tied to the looms. The agency of Daghshawl often became a source of oppression in the hands of its officers. Armed with the authority of rulers, the officials of this department subject the poor weavers to a great deal of tyranny, which in turn, often led to the forced migration of the shawl-weavers to Punjab. And when they succeeded in managing their escape in the face of a strict vigil on the passes leading to plains, the members of their families were not left in peace. No sooner did the weaver give up his job then the Karkhandar (cottage-industrialist) informed the darogah (police official) in order to get his tax decreased. The daragoh then sent a sepoy to the house of the fugitive. His wife or mother or father or probably all of them, were brought before the department of Daghshawl. They were fined a rupee or two or imprisoned for a few days by the authorities, whose cruelty and injustice has extorted.

The first ever labour of its kind was organized in, 1865. A. D, by the shawlbafs (shawl- weavers) in the city of Srinagar. The motive forces behind this rising were the miserable economic condition of the weavers. They were the lowest paid working class, and were subjected to inhuman treatment by their employers and the corrupt officials of the Daghshawl. The immediate cause of the labour rising was an oppressive measure adopted by the contractor of the Daghshawl, Pandit Rajkak Dhar, who was supposed to recover and pay to the state twelve lakh rupees. The taxation policy of the state was managed in such a way by the employers that its greater burden fell on the weavers. The weavers have to pay 49 rupees each as a contribution towards the sum of the 12 lakh rupees to be paid to the state. An ordinary weaver had, thus, to pay five rupees as tax out of his monthly income which ranged from seven to eight rupees. This intolerable policy forced them to unite and present a petition of their grievances to the Governor on, 29 April 1865. The shawl- weavers marched in a procession, towards Zaldagar, Srinagar. The processionist uttered slogans expressing their demands. They also burnt the effigy of Rajkak Dhar. They were ordered to disperse, but they refused. Troops were then sent under the command of Colonel Bajay Singh to crush the procession. They pouched on the unarmed and unguarded labourers and charged them with guns and spears. After some labourers died, the procession ran towards the bridge of Hajji Rather and most of them fell into the marshy canal and got drowned. Hundreds of workers suffered minor and major injuries and at the end 28 dead bodies were returned to the people.

The Kashmiri Pandits exclusively manned the Daghshawl department, which regulated the shawl trade. Whereas the Muslim shawl- weaver lived in a very chronic poverty, so much so that he could hardly manage two time meal. The Hindu officials associated with the collection of taxes from the shawl- weavers were living a pompous life. Maharaja Gulab Singh had imposed heavy taxes on shawl industry and levied other duties such as a pool tax of Rupees 47 per annum on each shawl- weaver. In order to ensure a constant flow of income he did not allow a worker, whether half blind or full blind, to leave his loom without a substitute. He also charged an advolerm duty of 25 percent on each shawl. Besides, his officials charged their illegal exactions which also amounted to 25 percent of the cost. In the face of such oppression the workers preferred to flee from the valley. Gulab Singh imposed tax on every shop at Rs. 120 per annum for old shops and Rs. 60 per annum for new shops. It was in 1897 the owners of the shawl factories as well as other workers were highly agitated and presented their grievances before George Taylor. The rack- renting policy of the state as well as the corrupt attitude of the authorities had turned the condition of the shawl- weavers deplorable. The discontentment of a big and local class of shawl- weavers provided a fertile ground to those few sensitive souls for inaugurating a new and sustained struggle against the Dogra rule. Kashmiri freedom fighters and their supporters voiced the downfall of the Kashmiri handicrafts and the resultant pathetic condition of the artisan class. The shawl weavers were not only discontented artisan of Kashmir in fact, all the artisans and craftsmen were hit hard by the 
economic depression and the importation of machine- made goods, as the handmade goods were unable to compete with the cheap machine made goods.

Silk industry was probably the only industry which maintained its flourishing condition throughout the period. It was a government undertaking, which provided livelihood to thousands of people. The Srinagar silk factory alone employed 5,000 workers. All those workers, it is to be noted, were Muslims and almost all the officials of the silk industry belonged to non- Muslim community. In the famous memorandum of 1924, submitted by the prominent Kashmiri Muslims to Lord Reading, the problems of the Muslim labour of silk industry were also highlighted. It also prayed for the appointment of Muslims on higher positions of silk industry.

In 1924, the labourers of this factory were paid daily wage of $4 \frac{1}{2}$ annas per head which was obviously too inadequate, especially in view of the rising cost of living and the huge profit it earned. The corruption was so rampant that the Kashmiri Pandit officials shamelessly pocketed even a part of their wages. The workers of the factory had constantly been complaining against the insufficiency of wages, the corruption of the officials and the tyranny of the inspecting staff. The contention of those labourers was that in addition to their low wages, they were insulted by the officials who demanded bribes from them. Besides, the silk factory of Srinagar also remained closed for two to three months in a year for which no wages were paid to the workers. The allegations of corruption were found to be true, but instead of taking action against the guilty they were mutually transferred from one block of the factory to another. It happened because the administration was entirely dominated by the Pandits who unfortunately considered it a part of their duty to protect each other. The failure of the government to punish the guilty officials especially when the allegation was proved true created a lot of resentment among the workers against the bureaucrats. The government in order to suppress the popular resentment of the workers arrested some of their ringleaders in July 1924. In order to register their protest and make a demonstration of their solidarity with their imprisoned comrades the entire labour force marched in a procession, joined by their women and children.

Hari Singh who was the commander -in- chief, rushed with a large force of cavalry and without any advance warning to disperse, ordered his troops, armed with fixed bayonets, to charge the strikers. Scores of people including women and children were trampled under and scores more were wounded by the bloodthirsty soldiers. Almost the entire Muslim sector of the city went without meals that evening because of the depth of feelings and sorrow. Though the labourers were able to gain an increase of six paisa per day in their wages but dozens of their leaders were sentenced to imprisonment. The state policy of patronizing non local industries and contractors caused a deep resentment among the Kashmiri labour class, as those non- local industries and contractors preferred to employ non-local labourers. It is strange that not only carpenters and masons, but more often than not, even unskilled labourers were imported from outside. Although the labour force was available in valley, the unemployment problems agitated the workers and their grievances were highlighted by Shaikh Muhammad Abdullah in the second annual session of Muslim Conference,1933.A.D.

The economic emancipation of masses was the most fundamental feature of the programmes and activities of the Muslim Conference and later on of National Conference. It always struggled for the welfare of the working classes like peasants, artisans and labourers who were the worst hit of imperial exploitation. The conference demanded the reduction of the land revenue and to provide latest technology and hybrid seeds to the peasantry. It was because of the efforts of the conference that number of concession was provided to working class and to all people as well. Thus, the conference played a commendable role towards the upliftment of the peasantry.

\section{CONCLUSION}

The authorities have really oppressed the people of valley. Confiscation of land and proprietary rights has resulted in the decline of economy. Economically people became very weak to a extent that they left their native places to other parts. To a greater extent people suffered a lot, but their continuous struggle resulted in the emergence of number of reformative movements that liberated people from the miseries of mismanagement.

\section{REFERENCES}

[1]. Francis Younghusband and Kashmui , Edinburg 1901,p, 161

[2]. Lord Birdwood, Two Nations and Kashmir, Robert Hall Ltd. Landon, 1995.

[3]. Cited in G.M. Rabbani’s Kashmir social and Cultural History. Almost Publications, Delhi 1986,pp.99100

[4]. M. Ishaq Khan, Perspective on Kashmir, Gulshan Publishers, Srinagar, 1983, p.47.

[5]. G.M.D. Sufi, Islamic Culture in Kashmir, light \& life Publishers, Delhi, 1979, p.279.

[6]. Baron Hugel, Travels in Kashmir and Punjab,English Translation, p.220

[7]. Lawrence, The India we Served, cited in Mohibul Hassan, (Fn.27)

[8]. G.H.Khan,Freedom Movement in Kashmir,Light and life Publishers, Delhi, 1980,p.19. 
[9]. Sisir Gupta, Kashmir: A Study in India- Pakistan Relations. Asia, Delhi

[10]. Balraj, Puri, Triamph and Tragedy of Indian Federalisation, Sterling, New Delhi, 1981,p.17

[11]. G.M.D. Sofi, Kashir, vol.iii, Light \& Life Publishers, New Delhi 1974, p.395.

[12]. Archaeological Survey Report of 1906-1907,p.161

[13]. Lawrence, W, The Valley of Kashmir, Kesar Publications, Srinagar 1967, p.16.

[14]. Tasir, Tehrik-i-Hurriyat-i-Kashmir, vol.i, pp.208-209.

[15]. Muhammad Yousuf Saraf, Kashmiris Fight for Freedom, vol.1, p.441.

[16]. Prem Nath Bazaz, The History of Struggle for Freedom in Kashmir, p.164.

[17]. Shaikh Muhammad Abdullah, Atish-i-Chinar, Srinagar, pp.227-228 